\title{
PRIORITAS PEMBERITAAN INJIL DALAM 2 KORINTUS 4:1-6
}

\author{
Lilis Setyarini, M.Th. \\ Sekolah Tinggi Teologi Injili Indonesia Surabaya \\ E-mail:lilissetyarini@sttii-surabaya.ac.id
}

\begin{abstract}
Priority Evangelists will be the object of study in this chapter focus on letter 2 Corinthians 4: 16. Where this topic is divided into four parts: Basic Services evangelist is because of God's mercy and receives the service. The second part talks about Exemplary Evangelists who should not lose heart in preaching the Gospel, Refuse act sneaky hidden and does not apply in the gospel. The third is the method in which the Not Faking Preaching the Word of God, Expressing Truth, Submit Yourself to Consider All People in the Face of God. Then the fourth is the focus of the preaching of the Gospel, in which the preacher must declare Jesus Christ as perso nal Lord and Herald as a servant who proclaim the greatness of Christ. Furthermore, the final section concludes with Affirmation of the news it self is Personal Testimony of Paul (of the light shine in the dark).
\end{abstract}

Keywords: Evangelists, letter 2 Corinthians 4: 1-6., Priority, Preaching.

\section{PENDAHULUAN}

Mengambil langkah yang pasti terkadang harus berbenturan dengan keadaan yang lain. Menyatakan sebuah kebenaran bukan tanggung jawab yang mudah bagi seorang Pemberita Injil, bukan hanya kebenaran yang harus dipertahankan tetapi kepribadian juga ikut dipertaruhkan.Orang Korintus mungkin pernah dan masih mempunyai pendidik dalam Kristus yang tidak terbilang jumlahnya untuk mendidik dan mengajar mereka di dalam kebenaran iman Kristen, mereka tidak mempunyai banyak Bapa. Kontras antara pembimbing dan ayah menjadi semakin jelas bila mengingata pendidik (kata Yunaninya paidagogos dan dari kata itu memperoleh kata "pedagog") adalah seorang hamba yang dipercaya yang membimbing anak-anaknya dari rumah orang tuanya kepada sang guru.

Hak Paulus untuk berbicara kepada orangorang Korintus sebagai anak-anaknya didasarkan pada kenyataan bahwa di dalam Kristus Yesus telah menjadi Bapa bagi mereka melalui pemberitaan Injilnya. Karena dialah yang pertama membawa Injil ke Korintus, tepatlah bila Paulus merasa harus melindungi seperti seorang ayah terhadap anak-anaknya. ${ }^{1}$ Surat 2 Korintus merupakan semacam surat pendamaian dan rujuk antara Paulus dan jemaat I Korintus. Hal ini terjadi antara waktu ditulisnya 1 Korintus dan 2 Korintus terjadi bentrokan hebat antara jemaat dan Paulus, dan juga Timotius yang dikirim Paulus tidak berhasil baik (1 Kor. 4:17, 16.10). Sebaliknya bentrokan menjadijadi dan meruncing pada waktu Paulus secara mendadak mengunjungi jamaat (2 Kor. 1:15, 2:5, 7:12), maka kunjungan itu tidak memperbaiki situasi. Lalu Titus dikirim untuk berusaha sekali lagi dengan membawa sepucuk surat tegas dari tangan Paulus (2 Kor. 7:13-15). Kali ini usaha Paulus membawa hasil yang diharapkan. Bagian terbesar jemaat menyesal dan mau berdamai dengan Paulus. Berita itu dibawa oleh Titus yang berjumpa Paulus di daerah Makedonia."Jadi 2 Korintus bermaksud memperteguh perdamaian yang sudah tercapai, meskipun masih terancam juga. Surat ini merangkumkan Pertikaian antara jemaat dengan Paulus."2 Paulus memilih mengunjungi jemaat di Korintus sewaktu Jemaat mulai terpengaruh dengan orang Yahudi yang membawa surat untuk

${ }^{1}$ V.C. Pfitzner, Kesatuan Dalam Kepelbagaian, Pentj. Sthephen Suleeman (Jakarta: BPK Gunung Mulia, 2006), 72

${ }^{2}$ C. Groenen OFM, Pengantar ke dalam Perjanjian Baru, 228 
memasukkan peraturan Hukum Taurat ke daldam Gereja.

Ketika Paulus menyatakan Kerinduannya untuk mengunjungi jemaat di Korintus dalam perjalanannya dari Efesus melalui Makedonia. Dia mengatakan "jika Tuhan menghendaki" sebab dia selalu bergantung kepada kehendak Allah (1Kor. 16:2-8). Dan oleh karena rencananya berubah, dia memberitahukan hal ini kepada jemaat Korintus (2Kor. 1:15, 16). Ada sejumlah orang yang menunggu-nunggu kesempatan untuk merendahkan integritas Paulus (2Kor. 10-13). Dan inilah kesempatan bagi para lawannya untuk menuduhnya sebagai tidak konsisten dan plin plan (2Kor. 1:17, 18).

Allah tidak dapat dimuliakan lewat tipu daya, selain itu hati nuranimu akan terganggu dan karaktermu akan terkikis. Ketika menjelaskan tentang rencananya yang berubah, Rasul Paulus menyisipkan penjelasannya untuk berbicara tentang kesetiaan Allah, keselamatan, pengudusan, dan jaminan kekal (2Kor. 1:19-22; Yoh. 10:22-30) dan bahwa Dia adalah tetap dan tidak berubah (Yak. 1:17), karena Allah tidak mungkin berdusta (Ibr. 6:18; Why. 3:14). Paulus mulai mempromosikan pengumpulan sumbangan dengan menunjuk pada telaladan jemaat-jemaat yang hidup di Makedonia. Teladan itu hendaknya memotifasi jemaat Korintus untuk turut aktif juga dalam pelayanan untuk orangorang kudus. Contoh baik yang diberikan jemaat Makedonia itu bukan hanya menyatakan solidaritas mereka, melainkan merupakan suatu gerekan anugerah Allah. ${ }^{3}$ Seperti halnya Paulus yang juga seringkali mendapatkan sesuatu yang kontra dengan panggilannya menjadi pemberita Injil, sebenarnya dalam Perjanjian Lama hal semacam ini juga terjadi pada nabi-nabi yang diutus Allah.Dalam sejarah dunia purbakala Allah hadir dalam eksistensi manusia. Wahyu Allah itu mendirikan persekutuan dengan manusia secara intensif ${ }^{4}$. Karena itu, nampak gejala kenabian yang sangat penting dalam peranannya sebagai penyambung lidah Allah. Dalam kesaksian Perjanjian Lama mengatakan bahwa nabi merupakan seorang yang menyampaikan Firman Allah kepada manusia.

\footnotetext{
${ }^{3}$ Ulrich Beyer \& Evalina Simamora, Memberi Dengan Sukacita (Jakarta: BPK Gunung Mulia, 2008), 53

${ }^{4}$ Kamus Besar Bahasa Indonesia,

Intensif: Secara sungguh-sungguh dan terus menerus dalam mengerjakan sesuatu sehingga memperoleh hasil yang maksimal.
}

Saat menghadapi tugas panggilan tersebut seorang nabi selalu diperhadapkan dengan situasi yang kontra dengan panggilan itu. Penyebab kontra terhadap panggilan itu oleh karena keterbatasan diri, kelemahan, tidak pandai bicara dan merasa diri kecil sehingga tidak layak untuk menyampaikan nasihatnasihat yang bersifat kebenaran. Konkrit situasi itu dapat dilihat dalam panggilan beberapa nabi yaitu: Yeremia, Yesaya dan Yunus.

Menurut Yeremia 1: 4-19, ketika ia dipanggil Tuhan menjadi nabi tahun 627, Yeremia enggan menerima panggilan itu karena masih terlalu muda sehingga dalam menjalani pelayanannya yang sulit selama 40 tahun menunjukan bahwa ia memang masih muda sewaktu dipanggil menjadi nabi. ${ }^{5}$ Tentu sebelumnya Yeremia telah mengajukan protes atau keberatan. Argumentasinya bahwa ia masih muda, merasa belum matang dan belum sanggup. Sebab di Israel kuno tua-tualah, yang biasanya memberi perintah dan nasihat-nasihat yang patut dihormati dan bukan pemuda. ${ }^{6}$

Kitab Yunus termasuk kitab kenabian yang paling muda dalam Perjanjian Lama. Yang menarik perhatian adalah bahwa kitab Yunus mendengarkan suara kritis tentang tugas kenabian yaitu bukanlah nubuat seorang nabi yang diucapkan tetapi kasih karunia Tuhan yang dari padanya manusia hidup. ${ }^{7}$ Sama halnya dengan Yeremia, Yunus pun mengalami pengalaman yang serupa. Allah memanggil Yunus untuk memberitahukan pesanNya kepada kota Niniwe karena kejahatannya yang besar. Namun suara panggilan itu, membuat Yunus harus melarikan diri jauh dari hadapan Tuhan menuju Tarsis. Amanat mulia ini dilawan oleh

\footnotetext{
${ }^{5}$ Derek Kidner, Yeremia (Yogyakarta: Yayasan Komunikasi Bina Kasih/OMF, 1996), 11

${ }^{6}$ Roberth M. Paterson, Tafsiran Alkitab - Kitab Yeremia (Jakarta: BPK Gunung Mulia, 2007), 39. Yeremia, putra seorang imam, lahir dan dibesarkan di Anatot, desa para imam (6 km di timur laut dari Yerusalem) selama pemerintahan Raja Manasye yang jahat. Yeremia memulai pelayanan sebagai nabi pada tahun ke-13 pemerintahan Raja Yosia yang baik, dan ia ikut mendukung gerakan pembaharuan Yosia. Akan tetapi, ia segera menyadari bahwa gerakan itu tidak menghasilkan perubahan yang sungguh-sungguh dalam hati bangsa itu; Yeremia mengingatkan bahwa jika tidak ada pertobatan nasional sejati, maka hukuman dan pemusnahan akan datang dengan tiba-tiba.

Alkitab. Sabda.org

${ }^{7}$ A. Th. Kramer, Tafsiran Alkitab - Kitab Yunus (Jakarta: BPK Gunung Mulia, 2003), 68
} 
kehendaknya sendiri yang berpandangan bahwa ia seorang muda yang tak mampu untuk melakukan tugas tersebut dan memiliki sikap partikularistik (Yun. 1: 1-17). ${ }^{8}$ Yunus merasa dongkol karena Allah mau memulihkan kota yang selama

ini sudah jahat kepada Allah. Didukung dengan sikap partikularistiknya, Yunus mulai berjalan sesuai dengan kehendaknya. Dia tidak lagi melihat yang prioritas yang harus menjadi tujuan hidupnya, sehingga dia lebih memilih untuk melarikan diri. Yunus berpikir mungkin pergi ke Ninewe bukan suatu hal yang penting baginya. Dari ketiga contoh panggilan nabi-nabi dalam Perjanjian Lama yang tertulis dia atas menyatakan, jika seorang pelayan Tuhan tahu mengutamakan yang prioritas Tuhan akan menyertai mereka dalam segala keadaan.

Pembentukan tradisi, perkembangan kanon dan kesaksian teks merupakan pokok-pokok yang saling berhubungan, karena Alkitab dimengerti sebagai karya Ilahi. Tuhan sendiri yang berperan dalam penyususnan teks Alkitab. ${ }^{9}$ Roh Kudus memberikan pengilhaman dan pencerahan kepada orang-orang yang dipilih untuk menyusun Alkitab, baik Perjanjian Lama maupun Perjanjian Baru.

Prioritas Pemberita Injil yang akan menjadi obyek penelitian dalam bab ini fokus pada surat 2 Korintus 4:1-6 yang berbunyi "Oleh kemurahan Allah kami telah menerima pelayanan ini. Karena itu kami tidak tawar hati. Tetapi kami menolak segala perbuatan tersembunyi yang memalukan; kami tidak berlaku licik dan tidak memalsukan firman Allah. Sebaliknya kami menyatakan kebenaran dan dengan demikian kami menyerahkan diri kami untuk dipertimbangkan oleh semua orang di hadapan Allah. Jika Injil yang kami beritakan masih tertutup juga, maka ia tertutup untuk mereka, yang akan binasa, yaitu orang-orang yang tidak percaya, yang

\footnotetext{
${ }^{8}$ Keselamatan hanya bagi bangsa Israel.

Partikularistik berasal dari partikularisme : 1 sistem yg mengutamakan kepentingan pribadi di atas kepentingan umum; 2 aliran politik, ekonomi, kebudayaan yg mementingkan daerah atau kelompok khusus; sukuisme. Kamus Besar Bahasa Indonesia

${ }^{9}$ Tafsir Alkitab Perjanjian Baru, ed. Dianne Bergant, CSA \& Robart J. Karris, OFM (Yogyakarta: Kanisius, 2002), 1

Alkitab adalah kumpulan dari tradisi keagamaan yang diakui sebagai suci karena diinspirasikan oleh Allah. Pengakuan resmi dari umat yang percaya, bahwa tradisi ini diinspirasikan, memberinya status kanonik. Ini berarti tradisitradisi ini memberi kewibawaan otoritas yang tidak dimiliki oleh tradisi lain yang terdapat dalam komunitas tersebut.
}

pikirannya telah dibutakan oleh ilah zaman ini, sehingga mereka tidak melihat cahaya Injil tentang kemuliaan Kristus, yang adalah gambaran Allah. Sebab bukan diri kami yang kami beritakan, tetapi Yesus Kristus sebagai Tuhan, dan diri kami sebagai hambamu karena kehendak Yesus. Sebab Allah yang telah berfirman: "Dari dalam gelap akan terbit terang!", Ia juga yang membuat terang-Nya bercahaya di dalam hati kita, supaya kita beroleh terang dari pengetahuan tentang kemuliaan Allah yang nampak pada wajah Kristus."

\section{TELADAN PEMBERITA INJIL (AY.1-2A)}

Gambaran lain yang cukup tepat untuk memahami arti pelayanan munculdalam 2 Korintus. Disini bukanlah gambaran tentang tubuh, melainkan pertentangan antara kegelapan dan terang yang menjadi titik sentral. "Teladan" Satu kata, tapi memerlukan begitu banyak kata untuk menjelaskannya. Menurut Kamus Besar Bahasa Indonesia "Teladan" mempunyai arti sesuatu yg patut ditiru atau baik untuk dicontoh ( perbuatan, kelakuan, sifat, dsb). ${ }^{10}$ Dengan kata lain "teladan" sangat berhubungan erat dengan perbuatan,kelakuan dan sifat seseorang. Perbuatan yang dianggap sebagai teladan bukan hanya sekedar perbuatan, namun kata ini terbatas hanya untuk perbuatan yang baik yang bisa dijadikan contoh orang lain.

Pagi-pagi benar Ia berada lagi di Bait Allah, dan seluruh rakyat datang kepada-Nya. Ia duduk dan mengajar mereka. Maka ahli-ahli Taurat dan orang-orang Farisi membawa kepada-Nya seorang perempuan yang kedapatan berbuat zinah. Mereka menempatkan perempuan itu di tengahtengah lalu berkata kepada Yesus: "Rabi, perempuan ini tertangkap basah ketika ia sedang berbuat zinah. Musa dalam hukum Taurat memerintahkan untuk melempari perempuanperempuan yang demikian. Apakah pendapat-Mu tentang hal itu?

Mereka mengatakan hal itu untuk mencobai Dia, supaya mereka memperoleh sesuatu untuk menyalahkan-Nya. Tetapi Yesus membungkuk lalu menulis dengan jari-Nya di tanah.

Dan ketika mereka terus-menerus bertanya kepadaNya, Iapun bangkit berdiri lalu berkata kepada mereka: "Barangsiapa di antara kamu tidak berdosa, hendaklah

\footnotetext{
${ }^{10}$ Kamus Besar Bahasa Indonesia,
} 
ia yang pertama melemparkan batu kepada perempuan itu."Lalu Ia membungkuk pula dan menulis di tanah. Yohanes 8:2-8, Yesus menunjukan "Teladan" dengan tidak menjadi hakim atas wanita zinah itu. Dia mengerti, bahwa selama kapasitas diriNya $100 \%$ manusia, Dia tidak berhak menghakimi. Karena penghakiman adalah hak-Nya Bapa.

Kisah keteladanan berikutnya adalah jangan memandang rendah orang lain. Ada begitu banyak kisah dimana Yesus bertemu dengan orang orang berdosa yang notabene dipandang rendah oleh manusia. Dia tidak menganggap diri-Nya lebih berharga dari orang berdosa itu. ${ }^{11}$ Ingat kisah Zakheus, si pemungut Cukai yang juga tukang peras? si pelacur Maria yang mengurapi Yesus dengan minyak? bahkan penderita kusta-pun, diterima-Nya dengan tangan terbuka, sebagai manusia yang patut dikasihani.

Firman Tuhan mengajarkan orang percaya untuk mengikuti teladan sebagai bagian dari Amanat Agung yang dikatakan Kristus "Karena itu pergilah, jadikanlah semua bangsa murid-Ku dan baptislah mereka dalam nama Bapa dan Anak dan Roh Kudus, dan ajarlah mereka melakukan segala sesuatu yang telah Kuperintahkan kepadamu. Dan ketahuilah, Aku menyertai kamu senantiasa sampai kepada akhir zaman." (Mat. 28:19-20).

Perintah "ajarlah mereka melakukan" tidak hanya dilakukan lewat pemberitaan Firman Tuhan, tetapi juga disertai dengan teladan hidup. ${ }^{12 "}$ Yesus menekankan pentingnya mematuhi perintahperintah-Nya. Salah satu tugas dari hamba-hambaNya ialah untuk mengajar tentang kepatuhan, sama seperti Yesus sendiri mengajarkan kepatuhan." Proses belajar lewat meneladani bukan sesuatu yang baru, tetapi jarang dipraktekan dalam kehidupan nyata. Kendala yang dihadapi adalah kurangnya orang-orang yang menjadi tutor atau teladan yang bukan hanya pandai menjelaskan tetapi juga melakukan apa yang dijelaskannya.Kembali didalam Amanat Agung, Kristus memerintahkan muridmurid-Nya untuk memuridkan segala bangsa. Proses ini bukan terjadi dalam bentuk pendidikan atau pemberitaan Firman Tuhan saja, tetapi proses pemuridan dilakukan melalui teladan hidup para

\footnotetext{
${ }^{11}$ Sabda.org, Alkitab Online

${ }^{12}$ Tafsiran Alkitab Masa Kini (Jakarta: Yayasan Komunikasi Bina Kasih/OMF, 1999), 122
}

rasul yang kemudian diteruskan kepada muridmurindnya dan seterusnya.

Menjadi seperti Kristus bukan berarti mengimajinasikan Yesus didalam angan-angan dan membayangkan dalam pikiran apa yang akan diperbuat-Nya, tetapi tahu apa yang diajarkan-Nya bukan dari imajinasi tetapi dari Firman Tuhan. ${ }^{13}$ Disinilah keteladanan itu dibutuhkan agar orang percaya tidak berimajinasi sesuai pikirannya sendiri, tetapi meniru teladan orang-orang yang telah meneladani Kristus.

Teladan dalam Alkitab Yunani memakai kata "Tupos" yang biasa juga diterjemahkan contoh, gambaran atau pola. Beberapa kali kata itu digambarkan sebagai patung, bekas dan kiasan yang semuanya merupakan jenis gambaran. ${ }^{14}$

Apa yang sudah diteladankan oleh Yesus, kemudian diteruskan oleh rasul-rasul-Nya. Paulus dalam 2 Korintus 4:1-6 berusaha membuktikan keteladannya dalam memenuh panggilannya sebagai rasul, sehingga ketika keteladanan itu harus dipertanyakan, Paulus tidak segan-segan untuk membantahnya. Predikat keteladanannya dalam memberitakan Injil menjadi bagian yang sangat penting dalam eksegesa karya ilmiah ini.

\section{DASAR PELAYANAN}

Pelayanan akan membawa sukacita, jika yang melakukannya memiliki dasar yang benar terhadap pelayanan itu. Karena tidak semua pelayan termasuk pemberita Injil, memulai tugas pelayanannya dengan didasari pada motifasi yang benar. Banyak pelayan Tuhan yang harus menyerah hanya karena sesuatu yang sepele.

Dasar yang kuat dalam menerima pelayanan akan menjadi penghiburan tersendiri, terutama ketika pelayan merasa lemah. Kemurahan Allah dan sanggup menerima pelayanan dengan hati yang

\footnotetext{
${ }^{13}$ Sabda.org

${ }^{14}$ David L. Baker, Satu Alkitab Dua Perjanjian (Jakarta: BPK Gunung Mulia, 2006), 204

"Tupos" dipakai hanya 17 kali dalam Alkitab Yunani (Septuaginta dan Perjanjian Baru) dan sama sekali tidak dipakai dalam istilah teknis. Kadang-kadang kata "Tupos" dianggap mempunyai arti teknis dalam Roma 5:14 dan 1 Korintus 10:6. Namun para penerjemah pada umumnya sependapat bahwa artinnya "gambaran, teladan". Mungkin justru untuk mencegah adanya implikasi istilah teknis, maka istilah-istilah modern mengelakkan istilah "tipe" untuk tupos. Secara gamblang dapat disimpulkan bahwa kata tupos dalam Alkitab dengan arti contoh, teladan, gambaran,atau pola.
} 
tulus akan membawa seorang pemberita Injil memiliki dasar yang kuat, sehingga ketika gelombang dan badai menyerang, mereka tidak akan goyah.

\section{Kemurahan Allah}

Untuk mengerti dengan benar apa yang dimaksud Alkitab tentang sebuah kata, maka perlu diuraikan asal-usul katanya (etimologi). ${ }^{15}$ Oleh kemurahan Allah kami telah menerima pelayanan ini. Kata kemurahan barasal dari kata hvleh,qhmen (eleethemen) dari akar kata evlee,w (eleeo), yang berarti membantu seseorang karena kasihan, belas kasihan, rasa kasihan, kemurahan. ${ }^{16}$ Sedangkan versi Liddell-Scott Lexicon menerjemahkan "eleethemen" sebagai mengasihani, menujukkan belas kasihan, harus dikasihani, kasihan, merasa kasihan. ${ }^{17}$

Terjemahan lain mengartikan memiliki belas kasihan atau iba pada seseorang, menunjukkan belas kasihan kepada seseorang, melakukan perbuatan belas kasih. ${ }^{18}$ Alkitab versi King James menerjemahkan kata kata evlee,w (eleeo) dengan memakai kata "mercy" yang berarti untuk mengasihani, untuk membantu yang menderita atau mencari bantuan, untuk membantu para korban, untuk membawa bantuan ketempat malang, mengalami rahmat. ${ }^{19}$

Dari berbagai sumber di atas dapat ditarik suatu kesimpulan bahwa palayan yang dilakukan bukan sekedar karena tugas, namun pelayanan itu diterima dan dilakukan karena Allah yang telah terlebih dahulu menaruh belas kasihan orang yang dikasihinya.

Adapun waktu Allah berbelaskasihan kepada orang yang dikasihinya adalah sudah terjadi pada waktu lampau. Pada waktu menerima kemurhan atau belas kasihan Allah orang percaya dalam keadaan pasif, artinya tidak ada usaha dari orang percaya karena itu murni dari Allah. Allah telah menjadi subyek yang aktif.

Kata evlee,w (eleeo) sendiri dipakai oleh Paulus sebagai penulis surat 2 Korintus untuk menggambarkan keadaan dirinya sendiri ketika

\footnotetext{
${ }^{15}$ W.R.F. Browning, Kamus Alkitab, 100

${ }^{16}$ Biblework versi Thayer Lexicon

${ }^{17}$ Biblework versi Liddell-Scott Lexicon

${ }^{18}$ Biblework versi Gingrich Greek Lexicon

${ }^{19}$ The Layman's Parallel Bible versi King James
} (Grand Rapids, Michigan: The Zondervan Corporation, 1991), 2860
Allah dengan penuh belas kasihan telah menyelamatkan dirinya. Allah yang terlebih dahulu telah mengasihani hidup Paulus. Dari sini dapat dimengerti bahwa pelayanan pemberitaan Injil adalah sebagai rasa ucapan syukur karena Allah yang telah berbelas kasihan kepada orang berdosa. Menerima Pelayanan

Kata "menerima" berasal dari bahasa Yunani Dia. tou/to( e;contej (dia touto ekhontes), ${ }^{20}$ dari akar kata e;cw (ekho) yang berarti, pertama, memiliki, memegang. Arti yang kedua menggunakan tangan untuk memahami sesuatu. Ketiga pakaian, senjata, pakai. Keempat, berarti secara harafiah dan kiasan seperti memegang sesuatu dengan aman. ${ }^{21}$

Dan jika kata e;contej (ekhontes) ini disertai dengan kata tou/to (touto) yang berfungsi sebagai demonstratif, maka akan ada penekanan khusus. Ada beberapa arti yang dipakai untuk menterjemahkan kata ini, yang pertama digunakan untuk menarik perhatian kepada orang atau obyek yang ditunjuk. Kedua, digunakan sebagai kata sifat. Ketiga, digunakan untuk kata benda maskulin. Keempat, digunakan untuk memberikan penekanan khusus untuk seseorang atau sesuatu yang telah disebutkan sebelumnya. ${ }^{22}$

King James memakai kata "have"23 untuk menterjemahkan kata "menerima". Sedangkan versi New International: "therefore since through God's mercy we have this ministry (oleh karena itu karena kemurahan Allah kami telah melayani)", tidak dijelaskan memakai kata apa, tetapi yang jelas justru penulis menegaskan bahwa ia telah melayani karena kemurahan. Secara tidak langsung penulis telah melakukannya berarti pula sudah menerima tugasnya untuk melayani.

Alkitab versi Living Bible memakai kata "it is God himself, in his mercy, who has given" 24 yang berarti dalam rahmatnya Allah sendiri telah memberi. Sedangkan kata yang dipakai dalam Alkitab versi New Revised Standart adalah therefore, since it is by God's mercy that we are

\footnotetext{
${ }^{20}$ Biblework versi Friberg Lexicon

${ }^{21}$ Evangelical A. Elwell, Evangelical Dictionary

of Biblical Teology (Michigan: Baker Books, 1984), 298

${ }^{22}$ Biblework versi Friberg Lexicon

${ }^{23}$ The Layman's Parallel Bible versi King James,

2860 
engaged in this ministry ${ }^{25}$ (oleh karena itu, karena dengan rahmat Allah kita terlibat dalam pelayanan ini). New Revised Standart menyatakan bukan penerimaan pelayanan itu dengan pernyataan bahwa ia sudah terlibat dengan pelayanan itu karena rahmat Allah.Alkitab Terjemahan sehari-hari menterjemahkan dengan "Kami melakukan pekerjaan ini karena kemurahan hati Allah". ${ }^{26}$ Terjemahan Alkitab sehari-hari langsung menyatakan dengan kata melakukan, artinya Penulis justru sudah melakukan pelayanan itu dengan kemurahan hati Allah, te rjemahan ini sama dengan terjemahan versi King James.

Keindahan pelayanan Perjanjian Baru yang diberikan Allah kepada Paulus, yang lebih unggul daripada pelayanan Musa, sudah memberi semangat kepada Paulus, pelayanan itu adalah kemurahan Allah dan tidak berpautan dengan untuk pelayanan itu. ${ }^{27}$

Kata "pelayanan" itu sendiri berasal dari kata diakoni,an (diakonian) dari akar kata diakoni,a (diakonia). ${ }^{28}$ Adapun diakonia diterjemahan: Pertama, bidang pelayanan umum. Kedua, melayani di bidang penyediaan makanan/bantuan materi. Ketiga, melayani dalam tugas yang khusus. Keempat, melayani dalam hal amal memberikan bantuan. ${ }^{29}$

Arti lain yang dipakai untu menerjemahkan kata "diakonia" Layanan, pelayanan, penyediaan,

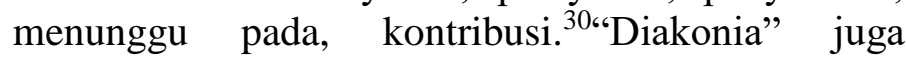
diterjemahkan "Pelayanan, melayani khususnya mereka yang melaksanakan perintah orang lain. Kedua, mereka yang oleh perintah Allah memproklamirkan dan mempromosikan agama diantara manusia." 31

Sedangkan "diakonia" menurut terjemahan Bahasa Inggris Living Bible dikatakan sebagai "pekerjaan yang indah". Jadi dari semua terjemahan dari berbagai versi seperti yang disebut diatas dapat disimpulkan bahwa diakonia adalah pelayanan yang khusus fokus kepada pelayanan yang berhubungan dengan bantuan materi, yang juga dikatakan sebagai

\footnotetext{
${ }^{25}$ The Layman's Parallel Bible versi Revised

Standart, 2861

${ }^{26}$ Alkitab Bahasa Indonesia Sehari-hari

(Bandung: Yayasan Kalam Hidup, 1993), 219

${ }^{27}$ Tafsiran Alkitab Masa Kini (Jakarta: Yayasan

Komunikasi Bina Kasih, 1999), 526

${ }^{28}$ Biblework versi Friberg Lexicon, Thayer

Lexicon, Louw-Nida-Lexicon

${ }^{29}$ Biblework versi Friberg Lexicon

${ }^{30}$ Biblework versi Louw-Nida-Lexicon

${ }^{31}$ Biblework versi Thayer Lexicon
}

pekerjaan yang indah.Tidak Tawar Hati Karena itu kami tidak tawar hati. Teladan hidup seorang pemberita Injil yang pertama adalah bahwa pemberita Injil harus memiliki sikap tidak tawar hati. Tawar hati dalam Kamus Bahasa Indonesia diterjemahkan: Pertama, tidak ada rasanya, perasaan hambar: kedua, hilang dayanya: ketiga, hilang keberanian; keempat, tidak gembira; kelima, tidak bernafsu; keenam, tidak menaruh perhatian; ketujuh, dingin (pada waktu menyambut tamu dsb): contoh kalimat: tawar hatiku setelah bertemu dengan dia. ${ }^{32}$

Tidak tawar hati berasal dari kata Yunani ouvk evgkakou/men (ouk egkakoumen), Kata ouvk (ouk) yang menyertai kata evgkakou/men (egkakoumen) memperkuat adanya negasi yang berarti bukan, tidak. ${ }^{33}$ Jika kata ini bergabung dengan kata yang lain berfungsi untuk menyangkal apa yang dinyatakan dalam kata kerja. ${ }^{34}$ Kata ouvk (ouk), memiliki aksen maka pernyataan yang terjadi adalah mutlak dan beraksen (istilah Yunaninya). ${ }^{35}$

Sedangkan kata evgkakou/men (egkakoumen) dari akar kata evgkake,w (egkakeo). ${ }^{36}$ Berarti kehilangan keberanian, tidak menyerah ${ }^{37}$, maksudnya dalam menghadapi pemberitaan Injil. Arti yang lain "tidak pernah putus asa". ${ }^{38}$ Kata evgkake,w (egkakeo) juga diterjemahkan menjadi jemu-jemu, menjadi tawar hati. ${ }^{39}$ Jika ditambah dengan ouvk (ouk) yang berarti "tidak" artinya menjadi tidak jemu-jemu atau menjadi tidak tawar hati.Untuk menerjemahkan ouvk evgkakou/men (ouk egkakoumen), New International memakai kata "we do not lose heart (kami tidak tawar hati)" ${ }^{\prime 4}$, ini sama persis dengan terjemahan Alkitab bahasa Indonesia. Sedangkan King James memakai kata "we faint not (kami tidak lemah)". ${ }^{41}$ Living Bible memakai kata yang lain

\footnotetext{
${ }^{32} \mathrm{http} / / /$ kamusbahasaindonesia.org/tawar hati

${ }^{33}$ Biblework versi Thayer Lexicon

${ }^{34}$ Biblework versi Friberg Lexicon

${ }^{35}$ Biblework versi Thayer Lexicon

${ }^{36}$ Ibid

${ }^{37}$ WBTC Draft (2006) @ SABDAweb 2Kor 4:1

${ }^{38}$ FAYH (1989) @SABDAweb 2Kor 4:1

${ }^{39}$ Harold K. Moulton, The Analytical Greek Lexicon Revised (Grand Rapids, Michigan: Zondervan Publishing House, 1979), 112 International, 2860

${ }^{40}$ The Layman's Parallel Bible versi New

${ }^{41}$ The Layman's Parallel Bible versi King James, 2860
} 
yaitu "so we never give up (kami tidak pernah menyerah)". ${ }^{42}$

Kata kerja kini aktif indikatif untuk menyatakan suatu proses yang sedang berlangsung. Aspek imperfektif ini mengandung nilai semantik yang lebih besar daripada aspek perfektif (aorist tense). Artinya, melalui tense ini terdapat kemungkinan si penulis hendak memberikan sorotan yang lebih besar terhadap suatu hal. ${ }^{43}$ Arti Kala Kini dalam Bahasa Yunani lebih menunjuk kepada sesuatu yang sedang dilakukan. Jadi lebih mendekati Present Continous dari pada Simple Present. Yaitu suatu pekerjaan/perbuatan yang sedang dilakukan atau yang dilakukan berulang-ulang dalam waktu sekarang. ${ }^{44}$

Dari apa yang sudah diteliti di atas dapat diambil kesimpulan bahwa tawar hati itu bukan sekedar sifat yang harus dimiliki oleh seorang Pemberita Injil melainkan sesuatu yang harus dikerjakan dan sedang dikerjakan, artinya lebih tepat menjadi tawar hati dan sifatnya terus menerus. Pemberita Injil adalah orang yang tidak pernah menyerah dan tidak gampang lemah dalam keadaan dan kondisi apapun.

\section{Menolak Perbuatan Tersembunyi}

Teladan Pemberita Injil yang kedua adalah Pemberita Injil menolak perbuatan tersembunyi (2 Kor. 4:2). Alkitab Bahasa Indonesia Sehari-hari menterjemakan "Kami tidak memakai cara-cara gelap yang memalukan. ${ }^{25}$ Sedangkan Kamus Besar Bahasa Indonesia menerjemahkan menutup-nutupi perbuatan jahat yg sudah diketahui orang ${ }^{46}$ namun karena penulis 2 Korintus mengatakan menolak perbuatan tersembunyi berarti penulis menolak menutup-nutupi/merahasiakan perbuatan jahat. Dengan kata lain menolak perbuatan tersembunyi adalah menolak perbuatan yang tidak terangterangan.Ada tiga kata yang dipakai untuk menyatakan menolak perbuatan tersembunyi, kata yang pertama adalah avpeipa,meqa (apeipametha) dari akar kata avpagoreu,w (apagoreuo) yang berarti menolak, menyangkal, ditetapkan,

2861

${ }^{42}$ The Layman's Parallel Bible versi Living Bible,

\footnotetext{
${ }^{43} \mathrm{http}: / /$ alkitab.sabda.org/resource.php?topict

${ }^{44} \mathrm{http}: / / \mathrm{www}$. sabda.org/sabdaweb/tools/lexicon

${ }^{45}$ Alkitab Bahasa Indonesia Sehari-Hari 46
}

http://pusatbahasa.kemdiknas.go.id/kbbi/index.php menyatakan, untuk melarang: untuk menyerah, meninggalkan. ${ }^{47}$

Kemudian ta. krupta. (ta krupta) kata sifat dari akar kata krupto,j (kruptos) yang berarti tersembunyi, rahasia, sesuatu yang tersembunyi. ${ }^{48}$ Yang ketiga adalah aivscu,nhj (aiskhunes) kata benda genetif dari akar kata aivscu,nh (aiskhune) yang berarti tingkah laku yang kotor, hal-hal yang memalukan, perbuatan yang memalukan seperti ketelanjangan yang memalukan. ${ }^{49}$

Melarang perbuatan tersembunyi yang memalukan atau meninggalkan perbuatan tersembunyi yang memalukan. Kata meninggalkan bentuknya aorist berarti perbuatan itu telah dilakukan oleh penulis pada waktu yang lampau dan akibatnya masih dirasakan sampai hari ini. Penulis sudah meninggalkan perbuatan tersembunyi yang memalukan itu. Pada saat memberitakan Injil penulis (Paulus) berani menjadi teladan bahwa ia tidak melakukan cara-cara yang hina agar Injil diterima, namun sebaliknya Paulus sudah membuang hal-hal itu jauh dari kehiupannya dan perbuatan itu telah selesai dilakukan.New Revised Standard "we have renounced the shameful things that one hides (Kami telah meninggalkan hal-hal memalukan yang tersembunyi). ${ }^{50}$ Penulis sebagai pemberita Injil tidak memakai cara-cara yang memalukan agar Injil bisa diterima, cara-cara memalukan yang tidak sesuai dengan kebenaran.

Terjemahan lain yang hampir sama yaitu "we do not try to trick people into believing (kami tidak pernah mencoba untuk mengelabuhi orang untuk percaya)." ${ }^{51}$ Dalam menyampaikan Injil penulis tidak pernah mengelabuhi orang untuk dapat percaya dengan apa yang disampaikan, maksudnya Injil yang diberitakan. Statement (pernyataan) ini muncul kemungkinan karena ada beberapa contoh orang yang berusaha mempengaruhi orang lain dengan cara-cara yang memalukan dengan kata lain menghalalkan semua cara untuk mendapat tempat di

${ }^{47}$ Harold K. Moulton, Lexikon Analitis Bahasa

Yunani yang Direvisi, Pentj. Robert J. Leland \& Stanley Pouw, ed. Tandi F. Randa (Yogyakarta: Randa'S Family

Press, 2009), 35

${ }^{48}$ Ibid, 223

${ }^{49}$ Harold K. Moulton, Lexikon Analitis Bahasa

Yunani yang Direvisi, 9

${ }^{50}$ The Layman's Parallel Bible versi New

Revised Standard , 2861

${ }^{51}$ The Layman's Parallel Bible versi Living 
hati orang lain. Kami tidak berusaha mengakali orang supaya mereka percaya. Kami tidak mengelabui orang. ${ }^{52}$ Pemberita Injil yang layak dijadikan teladan adalah pemberita Injil yang tidak menggunakan tipu daya yang jahat untuk mengelabuhi orang. Untuk membuat orang menjadi percaya pada pemberitaan Injil maka kejujuran itu sangat diperlukan.King James menerjemahkan dengan kalimat but have renounced the hidden things of dishonesty (tetapi telah meninggalkan hal-hal yang tersembunyi ketidakjujuran). ${ }^{53}$ King James membawa pada sebuah bentuk penerjemahan yang alami, karena memang perbuatan yang tersembunyi ini berhubungan dengan ketidakjujuran terutama dalam memberitakan Injil. Kejujuran mental adalah jujur terhadap hati nurani sendiri dan kesalahan menusia adalah karena mereka membohongi diri sendiri, karena realisme telah dibiarkan membunuh idealisme yang sejati. Kesungguhan dan kejujuran perlu berjalan terus dengan mengatakan menolak segala perbuatan tersembunyi yang memalukan. ${ }^{54}$

Injil tidak perlu disampaikan dengan segala tipu daya supaya orang menjadi percaya, tetapi Injil akan diterima jika pemberita memberikan teladan yang baik terutama dalam hal kejujuran. Yesus sendiri memberikan gambaran yang jelas tentang istilah perbuatan yang tersembunyi:

Pertama, Rasul-rasul palsu, pekerja-pekerja curang yang menyamar sebagai rasul-rasul Kristus (2 Kor. 11:13-15). ${ }^{55}$ Bagaimana dapat mendeteksi kepalsuan mereka? Tuhan Yesus memberi suatu petunjuk di Matius 7:20, "...Jadi dari buahnyalah kamu akan mengenal mereka." Hasil perbuatan atau pelayanan merekalah yang dapat dijadikan suatu tolok ukur kepalsuan mereka.

Kedua, Orang-orang yang melakukan perbuatan-perbuatan tersembunyi yang memalukan; mereka yang berlaku licik dan tidak mau dinilai oleh orang lain di hadapan Allah (2 Kor. 4:2). Mereka yang menyombongkan diri sendiri (2 Kor. 11:18).

Ketiga, Guru-guru Perjanjian Lama, yaitu para pemimpin agama atau orang-orang yang dipandang

\footnotetext{
${ }^{52}$ FAYH (1989) @ SABDAweb 2Kor 4:2

${ }^{53}$ The Layman's Parallel Bible versi King James,

${ }^{54}$ Anak Tangga Menuju Hidup Berkelimpahan,

${ }^{55}$ http://gkga-sby.org/content/view/636/
}

rohani oleh bangsa Israel pada zaman itu. Bagaimana sikap mereka? Mereka suka mengejek perihal kebangkitan (Kis. 17:31-32) dan juga mengajarkan bahwa tidak ada kebangkitan orang mati (2 Tim. 2:18). Mereka bersikap demikian karena mereka tidak memiliki pengharapan akan kekekalan di dalam Kristus (1 Kor. 15:19).

Paulus adalah seorang rasul yang berterus terang tentang realitas kehidupan dan pelayanan yang tengah dilakuyangkannya. Sejak menyerahkan diri untuk melayani Tuhan, masalah justru seakanakan enggan meninggalkannya. Ketika melayani jemaat di Korintus, ia pun tidak bebas dari masalah. Jemaat Korintus terkenal dengan reputasinya yang buruk. Banyak hal yang terjadi dalam jemaat ini, telah menyakitkan hati Allah dan Paulus. Misalnya perpecahan, juga tindakan tidak bermoral. Secara logika, sangat masuk akal bila Paulus mempertanyakan penyertaan Tuhan atas hidupnya, memprotes, atau bahkan mengambek. Namun, Paulus tidak melakukannya.

Ia tetap setia memegang komitmen pelayanannya. Paulus tetap bertahan bahwa dalam keadaan apapun tidak boleh melakukan perbuatan yang sifatnya mengelabuhi. Inilah inti "karakter pelayanan kristiani" sejati yang harus dimiliki oleh setiap pelayan Tuhan; di mana pun dan dalam peran apa pun. "Ditindas namun tidak terjepit ... habis akal namun tidak putus asa. ${ }^{56}$

\section{Tidak Berlaku Licik}

Licik menurut Kamus Bahasa Indonesia adalah melakukan tindakan yang berkenaan dengan manipulasi dan menipu untuk memperoleh apa yang diinginkan termasuk dengan menghalalkan segala cara dalam bahasa Indonesia kasar berarti akal bulus. ${ }^{57}$

Tidak berlaku licik, jika dilihat dari rumpun katanya mirip dengan menolak perbuatan tersembunyi, namun apa yang dinyatakan sama dalam Bahasa Indonesia belum tentu sama jika dilihat dari bahasa aslinya dan terjemahan lain. Jika dilihat dari bahasa aslinya "tidak berlaku" memakai kata mh. (me) adalah partikel negative untuk menyangkal dengan benar-benar secara langsung dan pasti. ${ }^{58}$ Sedangkan

\footnotetext{
${ }^{56}$ www.sabda.org/sabdaweb/bible/chapter

${ }^{57}$ Kamus Besar Bahasa Indonesia

${ }^{58}$ Harold K. Moulton, Leksikon Analitis Bahasa
}

Yunani yang Direvisi, 248 
kata "berlaku" diterjemahkan dari Bahasa Yunani peripatou/ntej (peripatountes) dari akar kata peripate, $\mathrm{w}$ (peripateo) ${ }^{59}$ yang berarti tanpa menambah, evn panourgi,a (en panourgia) licik, tipu muslihat, tipu daya, cerdik, siap berbuat apa saja, kebijaksanaan semu atau palsu. ${ }^{60}$

Jika kedua kata yang dipakai di atas digabung maka mh. peripatou/ntej evn panourgi,al (me peripatountes en panourgia) berarti menyangkal dengan tegas dan pasti dengan tanpa menambah kebijaksanaan yang semu atau palsu.panourgi,a (panourgia) Strong menerjemahkan sebagai setiap pekerjaan (jahat); perilaku (kiasan) licik; bermoral kelicikan yang berhenti pada apa-apa untuk mencapai tujuan egois. "Orang yang praktek panourgia (-pan + ergon) siap melakukan apa pun, hingga setiap trik"61 Kalimat yang dipakai oleh Alkitab versi New International adalah we do not use deception (kami tidak menggunakan penipuan $)^{62}$, sedangkan King James memakai kalimat not walking in craftiness (tidak berjalan didalam kelicikan) ${ }^{63}$, Alkitab versi New Revised Standard menggunakan kalimat "we refuse to practice cunning (kami menolak untuk berlatih licik)"64

"Paulus tidak mengatakan bahwa ia pernah berlaku licik (Yunani panourgia dipakai dalam 11:3 bagi penipuan iblis terhadap Hawa) sekalipun ia dituduh melakukannya."65 "Kelicikan biasanya dipakai oleh iblis untuk menjerat dan menyesatkan orang-orang." 66 Hal itu juga telah dilakukan oleh guru-guru palsu ketika mereka ingin menyebarkan ajarannya, mereka melakukan perbuatan yang memalukan dengan segala tipu daya seperti yang telah dilakukan iblis untuk menjerat Hawa.Syarat yang terpenting untuk menjadi pemberita Injil adalah sifatnya yang tidak bercela dan bias

\footnotetext{
${ }^{59}$ Biblework 7, program files versi Thayer

Lexikon

${ }^{60}$ Harold K. Moulton, Leksikon Analitis Bahasa

Yunani yang Direvisi, 278

${ }^{61}$ P. Hughs, Surat Kedua kepada Jemaat di

Korintus, 123.

${ }^{62}$ The Layman's Parallel Bible versi New

International, 2860

${ }^{63}$ The Layman's Parallel Bible versi King James,

2860

${ }^{64}$ The Layman's Parallel Bible versi New

Revised Standard, 2861

${ }^{65}$ Tafsiran Alkitab Masa Kini Jilib 3, 526

${ }^{66}$ J. Wesley Brill, Tafsiran Surat Korintus Yang

Kedua (Bandung: Kalam Hidup, 2003), 56
}

Menjadi teladan. ${ }^{67}$ Disamping menyombongkan diri, hidup orang Korintus dangat tidak senonoh. Mereka juga mencela Paulus itu seorang penakut, ia tidak tahu mengutarakan pikirannya dengan betul, ia mencari kehormatan diri sendiri saja, ia licik dan menjerat dengan tipu daya, tidak membangun tetapi malah merusak. ${ }^{68}$ Kata "panourgia" lebih sering dipakai untuk menyatakan perbuatan iblis yang penuh dengan tipu daya, tipu muslihat. Secara tidak langsung orang Korintus menyamakan Paulus melakukan perbuatan kelicikan atau tipu daya seperti iblis, namun Paulus menyangkalnya dengan tegas yang dalam bahasa Yunaninya memakai kata mh. (me), yang menunjukkan adanya penegasan negatif "tidak". Paulus berani menyatakan dirinya di hadapan semua orang bahwa ia tidak seperti iblis artinya berusaha menjerat orang lain dengan segala tipu muslihat untuk mengikuti ajarannya. "Para guru palsu telah memalsukan Firman Allah serta berlaku licik, sedangkan Paulus mengatakan yang benar dengan jelas dan berani." 69

Memberitakan Injil adalah suatu kewajiban bagi orang percaya, namun bukan berarti kewajiban itu dilakukan dengan menempuh segala cara/menghalalkan segala cara. Paulus memberikan teladan yang baik bagi pemberita Injil bahwa Injil harus tidak boleh diberitakan dengan segala kelicikan, tipu muslihat.

\section{METODE DALAM PEMBERITAAN (AY.2B-4)}

Selain menjadi teladan, seorang pemberita Injil tentunya memiliki metode untuk menyampaikan Injil. Metode berasal dari Bahasa Yunani "Methodos" yang berarti cara atau jalan yang ditempuh. $^{70}$ Fungsi metode berarti sebagai alat untuk mencapai tujuan. Bagaimana cara melakukan atau membuat sesuatu, Metode ilmiah, langkahlangkah yang ditempuh untuk memperoleh hasil ilmiah.Metode ilmiah atau proses ilmiah merupakan proses keilmuan untuk memperoleh pengetahuan secara sistematis berdasarkan bukti fisik. Ilmuwan melakukan pengamatan serta membentuk hipotesis dalam usahanya untuk menjelaskan fenomena alam.

\footnotetext{
${ }^{67}$ Ralph M. Riggs, Gembala Sidang Yang

Berhasil (Malang: Gandum Mas, 2003), 23

${ }^{68}$ Melihat Kedalam Perjanjian Baru, 106

${ }^{69}$ J. Wesley Brill, Tafsiran Surat Korintus Yang

Kedua, 57

${ }^{70}$ Kamus Bahsa Indonesia
} 
Prediksi yang dibuat berdasarkan hipotesis tersebut diuji dengan melakukan eksperimen. Jika suatu hipotesis lolos uji berkali-kali, hipotesis tersebut dapat menjadi suatu teori ilmiah.

Ketika memberitakan Injilpun Paulus menggunakan metode sesuai dengan konteksnya. Bahkan kehidupan Paulus adalah kehidupan yang menyaksikan Injil. Hal yang perlu diteladani adalah kehidupannya dipakai untuk memberitakan Injil (Rm.14:6). ${ }^{71}$

Paulus harus pergi dari rumah ke rumah, di hadapan umum dan secara pribadi memohon agar orang-orang bertobat kepada Allah dan beriman kepada Tuhan Yesus Kristus dan mengingatkan setiap orang siang dan malam dengan cucuran air mata. Itulah pelayanan Paulus.

Paulus merasa bertanggung jawab kepada Allah teradap orang-orang yang terhilang. Dalam Kisah Para Rasul 20:26 ia berkata, "Sebab itu pada hari ini aku bersaksi kepadamu, bahwa aku bersih, tidak bersalah terhadap siapapun yang akan binasa." Dengan kata lain Paulus berkata bahwa ia telah melakukan bagiannya, ia telah melakukan yang terbaik untuk memenangkan jiwa-jiwa yang terhilang bagi Kristus, dan tangannya bersih. ${ }^{72}$

Banyak sekali metode yang dipakai oleh Paulus dalam memberitakan Injil, namun metode yang dipakai di salah satu tempat tidak selamanya bisa diterapkan di tempat lain.

Cara kerja Paulus dalam memberitakan Injil adalah mula-mula berkhotbah di sinagoga atau rumah ibadat. Pendengar mereka adalah orang Yahudi dan non Yahudi (disebut sebagai orang yang takut akan Allah). Jika masyarakat Yahudi menolak Injil, maka pemberitaan dialihkan kepada masyarakat non Yahudi. ${ }^{73}$ Kutipan di atas merupakan salah satu metode Pemberitaan Injil Paulus, tetapi 2 korintus 4, menyajikan metode tersendiri dalam menyampaikan berita Injil kepada orang-orang di Korintus.

Tidak Memalsukan Firman Allah Salah satu metode yang dipakai oleh Paulus untuk memberitakan Injil adalah bahwa Paulus tidak memalsukan Firman Allah/perkataan Allah itu kepada orang alain. Alkitab Bahasa Indonesia Sehari-Hari menyatakan dengan kalimat "tidak memutarbalikkan perkataan

\footnotetext{
${ }^{71}$ Woo Young Kim, Yesuslah Jawaban, Penj. Seung Myung Ja Kim (Jakarta: BPK

Gunung Mulia, 2005), 203

72 Alkitab.sabda.org/commentary

${ }^{73}$ Hari Kustono, Pr., Paulus Dari Tarsus

(Yogyakarta: Kanisius, 2009), 23
}

Allah."74 Firman Allah dinyatakan secara jujur dan benar serta tidak direkayasa.

Kata "memutarbalikkan" dalam 2 Korintus 4:2 berasal dari Bahasa Yunani dolou/ntej (dolountes) dari akar kata dolo,w (doloo). ${ }^{75}$ Kata dolo,w (doloo) itu sendiri diterjemahkan merusak kebenaran ilahi dan mencampuradukkan dengan gagasan yang salah. ${ }^{76}$ Lexikon Analitis Bahasa Yunani Yang direvisi menerjemahkan sebagai umpan atau perangkap. $^{77}$

Sedangkan UBS Dictionary nenerjemahkan kata dolo,w (doloo) adalah mendistorsi, memalsukan. ${ }^{78}$ Louw - Nida Lexicon menerjemahkannya sebagai mendistorsi, menyebabkan kepalsuan. ${ }^{79}$ Paulus juga tidak memalsukan Firman Allah artinya dengan menerapkannya secara salah (bnd 2:17) atau tidak memperhatikannya (bnd 1 Kor. 9:21, 14:21), seperti yang agaknya dituduhkan oleh orang Yudais di Korintus. Firman Allah disini pertama-tama adalah Perjanjian Lama, tapi termasuk juga penyataanpenyataan Kristen. Bagi mereka yang pemikirannya tidak digelapkan, amaka cara Paulus menyampaikan kebenaran adalah cukup jelas. ${ }^{80}$ dolo,w (doloo) dalam New International dipakai kalimat nor do we distort the word of god (kami juga tidak merusak Firman Tuhan). ${ }^{81}$ Living Bible menggunakan kalimat we never try to get anyone to believe that the bible teaches what it doesn't (kami tidak pernah mencoba untuk mendapatkan orang untuk percaya pada apa yang tidak diajarkan Alkitab. ${ }^{82}$

Kata dolo,w (doloo) dalam terjemahan yang lain mempunyai arti tidak mengubah ajaran dari Allah, ${ }^{83}$ menyalahartikan Firman Allah. ${ }^{84}$

Sedangkan dalam Kamus Bahasa Indonesia "memalsukan" dari kata dasar palsu memilki arti: Pertama, tidak tulen; tidak sah; lancung (tt ijazah, surat keterangan, uang, dsb); Kedua, tiruan (tt gigi, kunci, dsb); Ketiga, gadungan (tt polisi, tentara, wartawan, dsb); Keempat, curang; tidak jujur (tt

\footnotetext{
${ }^{74}$ Alkitab Bahasa Indonesia Sehari-Hari

${ }^{75}$ Biblework 9

${ }^{76}$ Biblework 9 versi Thayer Lexikon

${ }^{77}$ Lexikon Analitis Bahasa Yunani Yang direvisi,

${ }^{78}$ Biblework 9 versi UBS Dictionary

${ }^{79}$ Biblework 9 versi Louw-Nida Lexicon

${ }^{80}$ Tafsir an Alkitab Masa Kini, 526

${ }^{81}$ The Layman's Parallel Bible versi New

International, 2860

${ }^{82}$ The Layman's Parallel Bible versi Living

Bible, 2861

${ }^{83}$ WBTC Draft (2006) (C) SABDAweb 2Kor 4:2

${ }^{84}$ KSI (2000) @) SABDAweb 2Kor 4:2
} 
permainan dsb); Kelima, sumbang (tt suara dsb). ${ }^{85}$ Injil seharusnya disampaikan tanpa penyimpangan atau gangguan, tidak boleh diputarbalikkan. Ketika iblis hendak membawa manusia pertama untuk jatuh ke dalam dosa, senjata yang paling ampuh yang dipakai adalah dengan memutarbalikkan Firman Allah. Iblis berkata kepada perempuan itu: "Semua buah yang ada dalam taman ini boleh engkau makan......sekali-kali kamu tidak akan mati, tetapi Allah mengetahui bahwa pada waktu kamu memakannya matamu akan terbuka dan kamu akan menjadi seperti Allah, tahu tentang yang baik dan yang jahat (Kej. 3:1-5).

Kisah dalam Kejadian 3 memberikan satu pemahaman bahwa contoh dari oknum yang memalsukan Firman Allah adalah iblis. Secara tidak langsung Paulus memberikan satu metode dalam memberitakan Injil adalah bahwa Firman itu tidak boleh dipalsukan, karena jika seorang pemberita Injil memalsukan Firman Allah berarti dia sudah menyamakan dirinya dengan iblis. Firman Allah tidak boleh diputarbalikkan hanya untuk kepentingan pribadi atau ambisi yang salah.

Di dalam 2 Korintus Paulus memberikan satu gambaran tentang pelayanan Kristen dengan mengatakan bahwa Tuhan telah melayakkan umatNya untuk memberitakan Injil. ${ }^{86}$ Artinya tugas memberitakan Injil itu bukan atas kemauan orang percaya sendiri tetapi atas kehendak Tuhan yang telah melayakkan umat-Nya. Firman Allah tidak boleh disampaikan dengan dan untuk kepentingan pribadi, mengatakan yang bukan kebenaran dijadikan benar seperti apa yang telah dilakukan oleh iblis kepada Hawa. Paulus mengingatkan kepada setiap orang percaya yang memberitakan Injil supaya jangan membuat berita palsu yang tidak sesuai dengan Firman Tuhan.Menyatakan Kebenaran

Kebenaran bukanlah suatu hal yang harus dipertimbangkan, demikianlah satu pernyaan Paulus yang disampaikan kepada orang percaya. Didalam memberitakan Firman Tuhan Paulus memberikan satu lagi metode yaitu menyatakan kebenaran.Kata menyatakan itu sendiri berasal dari bahasa Yunani fanerw,sei (fanerosei) kata benda datif feminim tunggal dari akar kata fane,rwsij (fanerosis) tindakan

85

http://kamusbahasaindonesia.org/palsu\#ixzz1RG3CIAMD

${ }^{86}$ Peter Adam, Speaking God's Words dalam A Practical Theology of Preaching (Vancaover, Canada: Regent College Publishing), 81 yang membuat pengumuman kepada publik secara jelas, pengungkapan.

Kamus Bahasa Indonesia memberikan beberapa arti untuk istilah "menyatakan" antara lain: pertama, menerangkan; menjadikan nyata; menjelaskan: ucapannya belum siapa di antara mereka yg bersalah; kedua, menunjukkan; memperlihatkan; menandakan: daftar itu betapa banyaknya korban yg jatuh; ketiga, mengatakan; mengemukakan (pikiran, isi hati); melahirkan (isi hati, perasaan, dsb); mempermaklumkan. ${ }^{87}$

Kebenaran dalam Kamus Bahasa Indonesia memiliki beberapa arti antara lain: Pertama, keadaan (hal dsb) yg cocok dengan keadaan (hal) yg sesungguhnya: kita harus berani mempertahankan -; ia masih menyangsikan -- berita itu; Kedua, sesuatu yg sungguh-sungguh (benar-benar) ada: kita harus menyakini -- yg diajarkan oleh agama; Ketiga, kelurusan hati; kejujuran: tidak seorang pun menyangsikan -- hatinya; Keempat, kl izin; persetujuan; perkenan: dng -- yg dipertuan, kami masuk istana; Kelima, Jk kebetulan: nah, -- dia datang sekarang, kita dapat bertanya langsung kepadanya. ${ }^{88}$

Kata kebenaran berasal dari bahasa Yunani avlhqei,aj (aletheias) dari akar kata avlh,qeia (aletheia) $^{89}$ dan memiliki beberapa arti pula: yang pertama, yang memiliki kepastian dan validitas; kedua, keadaan yang sesungguhnya, terutama karena kebenaran ilahi diungkapkan; ketiga, berhubungan dengan konsep dari pesan Injil sebagai kebenaran yang mutlak; keempat, fakta yang sejati; kelima, kebenaran, kesetiaan, kejujuran; keenam, realitas sebagai lawan dari kepura-puraan atau ketulusan.

Dan secara harafiahnya yaitu benar-benar, memang benar. ${ }^{90}$ LS Lexicon menerjemahkan kata avlh,qeia (aletheia): pertama, kebenaran; kedua, realitas; ketiga, kebenaran yang sesuai dengan realita, kejujuran,

ketulusan, keterbukaan, keterusterangan. ${ }^{91} \mathrm{Kata}$ avlh,qeia (aletheia) dalam versi Thayer lexicon berarti: pertama, kejujuran, kebenaran yang obyektif

87

http://kamusbahasaindonesia.org/menyatakan\#ixzz1Sc6HbWg r

88

http://kamusbahasaindonesia.org/kebenaran\#ixzz1RGJd7MuH

${ }^{89}$ Lexikon Analitis Bahasa Yunani Yang direvisi,

14

${ }^{90}$ Biblework 9 versi Friberg Lexicon
${ }^{91}$ Biblework 9 versi LS Lexicon 
(berlawanan dengan apa yang pura-pura, fiktif, palsu; kedua, keadaan yang sebenarnya dari kasus, dalam arti luas berbicara selalu menurut kebenaran; ketiga, kebenaran pada kenyataannya. ${ }^{92}$ Dalam hubungannya dengan agama kata ini menunjukkan hal-hal yang benar yang berhubungan dengan Allah dan tugas manusia (moral dan kebenaran agama). Kedua, gambaran tentang sifat sejati Allah. Ketiga, Kebenaran seperti yang diajarkan dalam agama Kristen, menghormati Allah dan pelaksanaan tujuanNya melalui Kristus, dan menghormati tugas-tugas manusia," menentang takhayul orang kafir dan penemuan orang-orang Yahudi, dan ajaran dari guruguru palsu di antara orang Kristen. ${ }^{93}$ Living Bible memberikan terjemahan "mengorbankan semua metode yang memalukan". 94

\section{Sedangkan New Revised Standard} menerjemahkan "menyatakan kebenaran secara terbuka." "95 Terjemahan New International adalah "menetapkan sebagai kebenaran."96 Terjemahan versi King James menerjemahkan sebagai "manifestasi dari kebenaran." $97 \quad \alpha \lambda \eta \theta \varepsilon 1 \alpha$ (alêtheia) adalah kebenaran secara budi, $\alpha \lambda \eta \theta \varepsilon ı \alpha$ (alêtheia) juga merupakan bahasa hukum yang bermakna "duduk perkara yang nyata" yang masih harus dibuktikan dengan kenyataan dan pernyataanpernyataan yang dipakai oleh para pihak dalam sebuah pengadilan. Dalam ilmu tentang sejarah, kata $\alpha \lambda \eta \theta \varepsilon 1 \alpha$ (alêtheia) bermakna 'duduk perkara yang nyata yang dikontraskan dengan dongeng. Dalam ilmu filsafat $\alpha \lambda \eta \theta \varepsilon i \alpha$ (alêtheia) bermakna, hal yang sungguh-sungguh nyata, dalam arti yang mutlak. Perjanjian Baru menghubungkan kata Yunani אממת (Emeth). Yohanes 14:6 Kata Yesus kepadanya: 'Akulah jalan dan kebenaran dan hidup. Tidak ada seorangpun yang datang kepada Bapa, kalau tidak melalui Aku. Mazmur 26:3 Sebab mataku tertuju pada kasih setia-Mu, dan aku hidup dalam kebenaran-Mu. Kedua ayat ini sama-sama menunjuk

\footnotetext{
${ }^{92}$ Biblework 9 versi Thayer Lexicon

${ }^{93}$ Evangelical A. Elwell, Evangelical Dictionary of Biblical Teology,

${ }^{94}$ The Layman's Parallel Bible versi Living Bible, 2861

${ }^{95}$ The Layman's Parallel Bible versi New

Revised Standard, 2861

${ }^{96}$ The Layman's Parallel Bible versi New International, 2860

97 The Layman's Parallel Bible versi King James,
}

pada kebenaran secara moral yang hanya didapat dalam Yesus. Hal yang hebat sekali mengenai Yesus ialah bahwa tidak hanya "pernyataan" mengenai kesempurnaan moral mencapai puncaknya di dalam Dia, tetapi juga "kenyataan" mengenai kesempurnaan moral mendapatkan realisasinya dalam Dia.

Ada satu yang penting mengenai kebenaran moral. Moral seseorang sebenarnya tidak mempengaruhi ajaran orang itu. Akan tetapi kalau seorang ingin mengajarkan kebenaran moral, bagaimana watak orang itu akan amat penting. Seorang yang suka berzinah bisa saja mengajarkan hal pentingnya kesucian. Seorang yang suka mencuri barang orang lain, bisa saja mengajarkan soal nilai kedermawanan. Seorang yang bernafsu untuk menguasai bisa saja mengajarkan tentang keindahan kerendahan hati. Seorang pemarah bisa saja mengajarkan tentang keindahan penguasaan diri. Seorang yang mendendam bisa saja mengajarkan tentang keindahan kasih. Namun, bagaimanapun juga semua yang diajarkan jika dilakukan dengan 'kepalsuan' itu tidak akan berhasil dan tak bernilai dimata Allah.

Kebenaran-kebenaran moral tidak bisa disampaikan hanya dengan kata-kata, tapi harus dengan contoh. Justru itulah yang tidak dapat dilakukan oleh guru manusia yang terbesar sekalipun. Tidak ada guru pernah menghayati dan mendarahdagingi kebenaran sepenuhnya apa yang ia ajarkan. Banyak orang dapat mengatakan, "Aku telah mengajarkan kebenaran kepadamu", tetapi tidak ada yang dapat berkata, "Akulah Kebenaran".

Jadi menyatakan kebenaran yang dipakai oleh Paulus sebagai meode memberitakan Injil dalam ayat ini adalah bahwa sebagai seorang pemberita harus bisa dengan jujur menyatakan apa yang benar. Kebenaran yang dimaksud adalah Yesus, pemberita Injil harus memberitakan Yesus.

Jika yang diberitakan adalah kebenaran bearti yang memberitakan juga adalah orang yang benar, jujur dan memiliki karakter yang bisa dipertanggungjawabkan.Menyerahkan Diri untuk Dipertimbangkan Semua Orang di Hadapan Allah Metode yang ketiga yang diungkapkan Paulus dalam 2 Korintus 4:2 adalah bahwa Paulus secara pribadi berani dipertimbangkan oleh semua orang di hadapan Allah. Hal ini akan dijadikan sebagai pembuktian oleh Paulus tentang apa yang telah dilakukannya 
Kalimat yang dipakai dalam Bahasa Yunani sunista,nontej e`autou.j pro.j pa/san sunei,dhsin avnqrw,pwn evnw,pion tou/ qeou/A (sunistatontes eautous pros pasan suneidesin anthropon enopion tou Theou). ${ }^{98}$ Untuk mendapatkan arti yang utuh kalimat di atas juga harus utuh, artinya tidak boleh sepotong-sepotong. Namun di sini juga akan diuraikan artinya satu persatu. Yang pertama akan diuraikan dulu kata sunista,nontej (sunistatontes) kata kerja partisip kini aktif nominative maskulin jamak dari akar kata suni,sthmi(sunistemi) berarti: pertama, menempatkan bersama-sama, untuk mengatur di tempat yang sama, membawa, untuk berdiri dengan (atau dekat). kedua, untuk menetapkan satu dengan yang lain dengan cara menyajikan atau memperkenalkan dirinya. ${ }^{99}$

Kata yang kedua adalah sunei,dhsin (suneidesin) kata benda akusatif feminism tunggal dari akar kata sunei,dhsij (suneidesis) artinya pertama, membedakan secara moral antara yang baik dan buruk; kedua, untuk mengajar dengan menggabungkan, membandingkan. ${ }^{100}$ Arti yang lain untuk kata sunei,dhsin (suneidesin) adalah mengetahui bersama akan sesuatu, setahu dengan, sadar, hati nurani bersih, hati nurani, suara hati, seperti kesadaran moral tentang tindakan dan prinsip diri. ${ }^{101}$

Alkitab Bahasa Indonesia Sehari-Hari menerjemahkan Sebab itu, kami harapkan semua orang menilai kami dengan baik di dalam hati nuraninya. ${ }^{102}$ Paulus menyatakan bahwa ia berani dipertimbangkan oleh banyak orang di hadapan Allah karena ia yakin bahwa ia bersih. Penilaian bukan dari diri sendiri, namun orang lain yang menilainya. Paulus berani dinilai orang lain asalkan berdasarkan kebenaran Allah.

Paulus membicarakan kelakuannya waktu dia berada bersama-sama orang Kristen di Kota Korintus dan menyatakan bahwa hati nuraninya bersaksi bahwa dia telah membawakan dirinya dengan tepat: inilah yang kami megahkan yaitu suara hati kami member kesaksian kepada kami bahwa hidup kami di dunia ini khususnya dalam hubungan kami dengan jemaat dikuasai oleh ketulusan dan kemurnian dari

\footnotetext{
${ }^{98}$ Biblework 9

${ }^{99}$ Biblework 9 versi Thayer Lexicon

${ }^{100}$ Ibid

${ }^{101}$ Lexikon Analitis Bahasa Yunani Yang direvisi,

102 Biblework 9 versi Bahasa Indonesia Sehari-
}

Hari
Allah, bukan nikmat duniawi tetapi oleh kekuatan kasih karunia Allah. ${ }^{103}$

Para guru palsu telah memalsukan Firman Allah serta berlaku licik, sedangkan Paulus mengatakan yang benar dengan jelas dan berani. Para Pemberita Injil yang dengan rendah hati dan mmurni memberitakan kebenaran sesuai dengan yang telah diilhamkan Tuhan kepadanya menyerahkan dirinya untuk dipertimbangkan oleh semua orang. Dan semua orang akan bersaksi bahwa mereka tulus dan murni. Paulus berlaku demikian di hadapan Allah dan juga manusia. Semua maksud dan tujuan Paulus adalah suci di hadapan Allah. Penilaian Allah lebih tinggi daripada penilaian manusia dan setiap pemberita Injil harus member pertanggungan jawab di hadapan Allah. ${ }^{104}$

Metode yang juga tidak kalah pentingnya adalah bagaimana seorang pemberita Injil menjaga hidupnya, sehingga ketika suatu saat ada yang mempertanyakan teladan hidupnya maka pemberita Injil dapat membuktikannya di hadapan manusia dan di hadapan Allah. Rasul Paulus telah membawa diri dengan baik sebagai pemberita Injil.

\section{FOKUS PEMBERITAAN (AY.5)}

Berbicara tentang fokus tentunya banyak orang yang tahu dan memahami. Kata focus sendiri Fokus Pemberitaan Injil adalah Yesus Kristus sebagai Tuhan dan juruselamat. Mengapa ini perlu ditekankan karena seringkali pemberita Injil sudah tidak fokus dalam pemberitaan Injil hanya karena ada sedikit masalah. Pemberita Injil harus tahu mana yang menjadi inti utama dalam menyampaikan Injil.

Fokus berarti. pertama, Fis titik atau daerah kecil tempat berkas cahaya mengumpul atau menyebar setelah berkas cahaya itu menimpa sebuah cermin atau lensa, berkas cahaya yg datang berada dl keadaan paralel dng sumbu cermin atau lensa itu; titik api: tempatkan objek itu dl -- kalau menginginkan hasil pemotretan yg bagus; kedua, pusat: -- perhatian dunia internasional tertuju ke kejuaraan sepak bola dunia di Prancis; ketiga, Ling a unsur yg menonjolkan suatu bagian kalimat sehingga perhatian pendengar (pembaca) tertarik pd bagian itu; b ciri predikat verbal yg menentukan

${ }^{103}$ Jerry White, Kejujuran Moral dan Hati Nurani (Jakarta: BPK Gunung Mulia, t.t), 16

104 J. Wesley Brill, Tafsiran Surat Korintus Yang

Kedua, 56-57 
hubungan semantis predikat verbal itu dng subjek, biasanya ditandai oleh afiks verbal; ber-fo-kus $v$ berpusat: ceramahnya pd masalah usaha peningkatan hasil pertanian; mem·fo·kus $v$ menuju fokus atau pusat; mem·fo·kus·kan $v$ memusatkan (perhatian, pembicaraan, pandangan, sasaran, dsb): mereka pembicaraan pd masalah pencalonan presiden dan wakil presiden;pem·fo·kus-an $n$ proses, cara, perbuatan memfokuskan; pemusatan (perhatian, pandangan, pembicaraan, dsb); ter.fo-kus $v$ terpusat: dl belajar bahasa asing, perhatian murid harus ${ }^{105}$

Dalam Bahasa Sehari-Hari "fokus" lebih dimengerti sebagai pusat atau inti. Pusat dari Pemberitaan Injil dalam 2 Korintus 4:1-6 ini dengan jelas ditulis oleh bahwa hanya Yesus pusat yang menjadi pemberitaan. Paulus dengan jelas mengatakan tentang keTuhanan Yesus Kristus dengan satu kalimat: "Sebab bukan diri kami yang kami beritakan, tetapi Yesus Kristus sebagai Tuhan (2 Kor 4:5a)"

\section{Yesus Kristus Sebagai Tuhan}

Paulus menempatkan fokus pemberitaan Injilnya adalah Yesus Kristus yang diberitakan sebagai Tuhan dan Juruselamat manusia. Ada banyak nama Yesus di dalam Perjanjian Baru, ada Yesus Barabas dll.

Fokus pemberitaan Injil dalam 2 Korintus 4:5 adalah Yesus Kristus. Alkitab Bahasa Indonesia Sehari-Hari menyatakan bahwa berita itu adalah berita tentang Yesus Kristus. Jadi apa yang diberitakan adalah tentang Yesus Kristus sebagai Tuhan.

Yesus Kristus yang dimaksud adalah cristo.n VIhsou/n (Khriston Iesoun): Yesus, Anak Allah, Juruselamat umat manusia. Dalam Perjanjian Lama sama artinya dengan Yoshua. ${ }^{106}$ Akar katanya dari

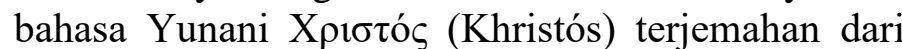
Mesias (Al Masih), artinya Yang Diurapi. ${ }^{107}$ abad 1 Masehi Masyarakat yang mengatakan pengikut Yesus Kristus sebagai "seperti Kristus" (Christlike).

Dalam naskah Yunani seluruh kata Tuhan untuk Yesus adalah Kurios. Kurios memiliki arti Tuhan dan Tuan. Jadi Yesus bisa dikatakan Tuhan bisa juga tuan. Bahasa Inggris (King James Version) menerjemahkannya dengan Lord dan lord.
Yesus Kristus merupakan sebuah nama dan sebuah gelar/sebutan. Nama Yesus dalam bahasa Yunani adalah Iesous; Kata itu berasal dari Jeshua/Joshua (bahasa Ibrani) yang artinya "Yehuwa Juruselamat" atau "TUHAN menyelamatkan". ${ }^{108}$ Sebutan Kristus dalam bahasa Yunani adalah Christos, yang bahasa Ibrani : Mashiach, yang artinya "Yang diurapi". ${ }^{109}$ Tanpa diragukan lagi dari nama Yesus sendiri, diketahui Siapakah Yesus sebenarnya, yang adalah Yehuwa yang menyelamatkan. Jadi tidak masuk akal, jika ada yang berkata bahwa itu hanya arti saja, karena secara tegas Yesus itu disebut sebagai Yehuwa yang menyelamatkan. Nama Yesus diartikan YehuwaJuruselamat, bukan sekedar arti saja, tetapi merujuk/menjelaskan Siapakah/Hakikat Pribadi yang memakai Nama itu. Karena dalam dunia ini, tidak ada pribadi yang namanya mendapat sebutan Allah atau namanya diartikan sebagai Allah, selain Nama Yesus.

Lukas 2:11, "Hari ini telah lahir bagimu Juruselamat, yaitu Kristus, Tuhan, di kota Daud." Padahal dalam Yesaya 43:11 dikatakan bahwa tidak ada Juruselamat selain TUHAN/Yehuwa/Allah $\mathrm{saja}=$ "Aku, Akulah TUHAN dan tidak ada Juruselamat selain dari padaKu". Dalam Injil dikatakan bahwa Yesus adalah Juruselamat. Oleh sebab itu mengapa setan-setan takut akan nama Yesus? Jika Yesus bukan Yehuwa, tentunya setansetan itu tidak takut padaNya, karena setan-setan tahu siapakah Yehuwa itu, yang telah menjadi manusia. (Mrk. 16 :17,"...........mereka akan mengusir setan-setan demi nama-Ku........”)

Ketuhanan Yesus Kristus dinubuatkan dalam Perjanjian Lama dan ayat-ayat mengenai Yesus Kristus dikutip dalam Perjanjian Baru. Dalam Yohanes 8:56-58, Matius 26:61-65, Yohanes 10:3033. Yesus Kristus mengaku bahwa diri-Nya Allah. Dalam Ibrani 1:8, Yohanes 1:18. Yesus Kristus dengan tegas disebut Allah. Dalam Yohanes 20:28 Thomas menyebut Dia Tuhanku dan Allahku. Pengakuan ini diterima oleh Yesus Kristus dan dalam hal itu berarti Dia mengaku diri-Nya Allah. ${ }^{110}$ "Yesus Kristus adalah Tuhan dan Juruselamat, yang hidup kira-kira duaribu tahun yang lalu di Palestina. Allah telah menyatakan kehendaknya
${ }^{105}$ Kamus Bahasa Indonesia

${ }^{106}$ Biblework 7 versi Thayer Lexicon

${ }^{107}$ Lexicon Analitis Bahasa Yunani Yang Direvisi,

\author{
108 Ibid, 185 \\ ${ }^{109}$ Sabda.org \\ ${ }^{110}$ J. Wesley Brill, Dasar Yang Teguh (Bandung:
}

Yayasan Kalam Hidup, 1999), 81 
yang menyelamatkan."111 Yesus Kristus telah membuktikan ketaatan dan kasih-Nya di atas kayu salib untuk menebus dosa manusia.

Dalam perjalanan-Nya keliling Ia seorang guru yang mengajarkan dengan penuh wibawa perihal kerajaan Allah Bapa-Nya. Sementara itu Ia mengumpulkan murid-murid pria dan wanita yang berdatangan dari segala penjuru. Mereka mengikuti Tuhan Yesus untuk mendengarkan sebelumnya. Lagipula mereka menyaksikan pekerjaan-pekerjaan ajaib, mujizat-mujizat dan bahkan bagaimana Tuhan Yesus mengusir setan dan tentarakegelapan atas perintah-Nya. Peristiwa-perstiwa menakjubkan yang disaksikan ribuan orang pengikut-Nya menimbulkan perselisihan pandang yang tajam dikalangan masyarakat walau perbuatan-perbuatan Tuhan Yesus yang supernatural itu tidak dapat dipungkiri. Maka rasul Yohanes dengan maksud mau meniadakan keragu-raguan pada rekan-rekan pengikut Tuhan Yesus tentang pribadi-Nya menyatakan: "Memang masih banyak tanda lain yang dibuat Yesus di depan mata murid-murid-Nya, yang tidak tercatat dalam kitab ini, tetapi semua yang tercantum di sini telah dicatat, supaya kamu percaya, bahwa Yesuslah Mesias, Anak Allah, dan supaya kamu oleh imanmu memperoleh hidup dalam nama-Nya. " (Yoh. 20: 30$31)$.

Injil kami, kata Paulus ialah Injil tentang kemuliaan Kristus. "Sebab bukan diri kami yang kami beritakan, tetapi Yesus Kristus sebagai Tuhan (ay. 5). Paulus berkhotbah bukan supaya dirinya dipuji, ditinggikan dan dipuja, melainkan supaya Kristus dipermuliakan dan ditinggikan. Paulus berkhotbah bahwa Yesus Kristus, Mesias dan Anak Allah, Juruselamat dunia ini adalah Tuhan. Hal ini dilakukannya supaya orang-orang menerima Yesus Kristus sebagai Tuhan dan Juruselamat mereka secara pribadi. ${ }^{112}$ Dalam naskah Yunani seluruh kata Tuhan untuk Yesus adalah Kyrios. Kurios memiliki arti Tuhan dan Tuan. Jadi Yesus bisa dikatakan Tuhan bisa juga tuan. Bahasa Inggris (King James Version) menerjemahkannya dengan Lord dan lord. Dalam bahasa jawa 'Gusti'. "кvpıs - KYRIOS" adalah salah satu gelar Yesus Kristus, yang dalam Alkitab Perjanjian Baru diterjemahkan khusus untuk Yesus Kristus dengan kata Indonesia "Tuhan".

${ }^{111}$ J.L Ch. Abineno, Pokok-Pokok Penting Dari Iman Kristen (Jakarta: BPK Gunung Mulia, 1999), 88

Kedua, 59
${ }^{113}$ Yesus Kristus yang adalah Tuhan yang diberitakan oleh Paulus adalah Yesus yang menerima penyerahan segala sesuatu dari Allah Bapa. Yohanes 3:35: "Bapa mengasihi Anak dan telah menyerahkan segala sesuatu kepada-Nya". Hal ini jelas sekali membuktikan bahwa Ia adalah benarbenar Tuhan.

Dari apa yang telah ditulis diatas nyata bahwa Paulus memberitakan Tuhan yang benar, Yesus Kristus yang adalah Tuhan yang menjadi inti pemberitaan Injilnya, bukan fokus pada pribadi pemberita. Paulus menyatakan bahwa pemberita adalah hamba yang hanya sekedar menjalankan tugas yang diberikan tuannya.

\section{Pemberita Sebagai Hamba}

Kenyataan yang sesungguhnya dalam pemberitaan Injil adalah bahwa Kristus sebagai Tuhan dan pemberita Injil sebagai hamba. Paulus sebagai pemberita Injil menyebut dirinya sebagai hamba Yesus Kristus. Kamus Besar Bahasa Indonesia menjelaskan ada beberapa arti tentang hamba antara lain: Pertama, abdi; budak belian: Kedua, kl saya (untuk merendahkan diri): Hamba tidak berani mengatakannya, Tuanku. ${ }^{114}$

Hamba (2 Korintus 4:5) dalam bahasa Yunani berasal dari kata dou,louj kata benda akusatif maskulin jamak dari akar kata dou/loj yang berarti: Partama, seorang budak, budak, pria kondisi budak; Kedua, seorang hamba, petugas (raja); Ketiga, orang yang menyerahkan dirinya untuk orang lain. ${ }^{115}$

Seorang doulos adalah seorang hamba yang terikat melayani tuannya seumur hidup. Kata doulos adalah juga kata yang berasal dari douleuo yang dalam Yunani modern berarti "bekerja, dan bekerja keras". Menurut hukum Perjanjian Lama, seorang hamba yang telah bebas dari perbudakan, bisa menjadi hamba bagi tuannya seumur hidup atas keinginan dirinya sendiri karena kasih: "Tetapi apabila dia berkata kepadamu: aku tidak mau keluar meninggalkan engkau, karena ia mengasihi engkau dan keluargamu, sebab baik keadaannya padamu, maka engkau harus mengambil sebuah penusuk dan menindik telinganya pada pintu, sehingga ia menjadi budakmu untuk selama-lamanya. Demikian

\footnotetext{
${ }^{113}$ Yohanes Bambang C.W., Kristologi

(Mojokerto: Gereja Ortodox Indonesia, t.t),114

http://kamusbahasaindonesia.org/hamba\#ixzz1SdgqSviv

${ }^{115}$ Biblework 9 versi Thayer Lexicon
} 
juga kau perbuat kepada budakmu perempuan" (Ul. 15:16-17). Dalam konteks Kristen-Yudea, seorang hamba yang terikat berarti seseorang menyerahkan diri sepenuhnya untuk melakukan kehendak dan perintah tuannya, bukan karena paksaan, tetapi karena karena kasih (Mat. 8:9).

Paulus telah menobatkan Kristus sebagai Tuhan atas seluruh kehidupannya dan atas setiap kelakuannya, karena itulah ia memperhambakan dirinya kepada semua orang, itulah hasil kasihnya kepada Kristus. Hamba Kristus dan hamba semua orang menjadi kemuliaan tertinggi bagi setiap pemberita Injil. ${ }^{116}$

2 Korintus 4:5 menyatakan "bukan diri kami yang kami beritakan, artinya bukan untuk kepentingan diri sendiri." ${ }^{117}$ Terjemahan lain mengatakan "Kami adalah hamba Saudara sekalian oleh sebab apa yang telah dilakukan oleh Yesus bagi kami."

Paulus mengatakan keberadaannya sebagai seorang hamba Kristus Yesus, yang oleh kemurahan Tuhan diberi kasih karunia untuk memberitakan Injil Tuhan. Sebagai hamba, Paulus menyatakan kesetiannya kepada Tuhan karena kasih Tuhan. Karena sadar posisinya sebagai hamba, maka dalam memberitakan Injil Paulus tidak menonjolkkan dirinya, melainkan Kristus yang ditonjolkan. Injil diberitakan bukan untuk kepentingan Paulus, namun Injil diberitakan adalah untuk kepentingan kemuliaan Kristus, sehingga sudah selayaknya Paulus bekerja keras untuk melakukan tugasnya itu sebagai interpretasi dari kata doulos.

\section{PENUTUP (AY. 6)}

Penutup dari teladan hidup dan metode pemberitaan Injil Paulus adalah kesaksian pribadi Paulus. Kesaksian ini dimaksudkan untuk meneguhkan apa yang telah diberitakannya, bahwa Pemberita juga mengalami pertolongan dan lawatan Tuhan di dalam hidupnya.Kesaksian pribadi yang disampaikan saat memberitakan Injil seringkali juga member kekuatan bagi orang lain. Paulus meneguhkan pemberitaan Injilnya dengan apa yang sudah dia alami ketika pertama kali dipanggil oleh Tuhan untuk melayani.Istilah dari dalam gelap akan terbit terang (ay.6) merupakan refleksi dari apa yang telah dialami Paulus. Paulus yang dulunya hidup dalam kegelapan karena tidak mengenal akhirnya

${ }^{116}$ J. Wesley Brill, Tafsiran Surat Korintus yang

Kedua, 59

$$
\begin{aligned}
& { }^{117} \text { Tafsiran Alkitab Masa Kini, } 526 \\
& { }^{118} \text { FAYH (1989) (C SABDAweb 2Kor 4:5 }
\end{aligned}
$$

Tuhan membuat satu perkara yang besar sehingga dia boleh percaya dan akhirnya menjadi pemberita Injil. Titik balik atau titik perubahan hidup Paulus adalah kisah pertobatannya yang terjadi dalam perjalanannya ke Damsyik. Hal ini tampak jelas dari bagaimana penulis Kisah Rasul mengisahkan pertobatan Paulus sampai tiga kali yakni Kisah Rasul 9:1-19, Kisah Rasul 22:1-22, Kisah Rasul 26:12-23. ${ }^{119}$ Peristiwa luar biasa yang terjadi dalam kehidupan Paulus dialaminya di jalan menuju Damsyik. Kisah Para Rasul 9:1-3 merupakan ayat dimana Paulus dengan kuasa Imam akan membasmi pengikut Yesus di Damsyik. Lalu tiba-tiba di ayat Kisah Para Rasul 9:4-5 / 15-17, Yesus memilih Paulus dengan suara ghaibnya.

Pertobatan Paulus merupakan salah satu peristiwa terbesar sejarah kekristenan. Paulus telah bertanggung jawab atas begitu banyak kematian dan ribuan orang-orang Kristen yang dipenjarakannya. Sekarang ia ada dalam perjalanan menuju Damsyik, sebuah kota penting di Siria, untuk mengusir orang-orang Kristen di sana.Ada tiga peristiwa dari pengalaman pertobatan Paulus yang tercatat di dalam Perjanjian Baru. Lukas menceritakannya menurut kenyataan sejarah dan Paulus menceritakannya dengan kata-katanya sendiri sebanyak dua kali (semua dapat ditemukan dalam Kitab Kisah Para Rasul). Paulus telah membuat namanya ditakuti di antara semua orang Kristen di Yerusalem. Dia telah berhasil memisahkan atau membungkam banyak orang Kristen di kota suci itu. Kemudian, ia mendapat laporan tentang adanya kelompok besar orang Kristen di kota Damsyik. "Kota Damsyik, kira-kira $240 \mathrm{~km}$ jauhnya dari Yerusalem." ${ }^{20}$ Dia memutuskan untuk pergi ke sana untuk melanjutkan penganiayaannya kepada orang-orang percaya ini. Dia telah diberi kekuasaan penuh dan membawa surat izin untuk memasuki kota dan menangkap semua orang Kristen di kota itu dan membawa mereka kembali dalam keadaan terbelenggu ke Yerusalem. Paulus dan kawan-kawan memulai perjalanan yang panjang menuju Damsyik. Perjalanan ini membutuhkan waktu enam sampai tujuh hari dan selama perjalanan panjang ini anak muda yang pandai dan penuh semangat ini mempunyai banyak waktu untuk berpikir. Mungkin ia mulai meragukan tindakannya. Dia tidak habis

${ }^{119}$ E. Martasudjita, Pr., Spiritualitas Damai

(Yogyakarta: Kanisius, 2008), 22

${ }^{120}$ Ensiklopedi Alkitab Masa Kini, 
berpikir dan tidak mengerti bagaimana Stefanus bisa mati dengan begitu tenangnya. Dia tidak dapat melupakan doa Stefanus ketika Stefanus "menutup mata" dengan damai. Paulus merasa bahwa dia harus melakukan hal yang ia pandang benar, tetapi dia terganggu oleh pertanyaan-pertanyaan yang tidak dapat dijawabnya. Oleh karena itu, ia pun pergi ke Damsyik.Berita tentang kedatangan Paulus telah sampai ke Damsyik sebelum ia tiba di sana. Pertobatan Paulus terjadi ketika ia mendekati kota itu. Pada waktu tengah hari, tiba-tiba sebuah cahaya yang membutakan mata bersinar mengelilingi Paulus dan teman-temannya. Ia rebah ke tanah dan kedengaranlah suatu suara berkata kepadanya, "Saul, Saul mengapa engkau menganiaya Aku?" Jawab Saulus: "Siapakah engkau, Tuhan?" Kata-Nya: "Akulah Yesus yang kau aniaya itu. Tetapi bangunlah dan pergilah ke dalam kota, di sana akan dikatakan kepadamu, apa yang harus kauperbuat." (Kis. 9:4-6).

Paulus berdiri dari tanah dan mendapati dirinya buta. Beberapa anak buahnya menuntun dia dan membawanya ke Damsyik. Selama tiga hari lamanya dia tidak dapat melihat dan tidak makan ataupun minum. Pengalaman ini mengubah Paulus sepenuhnya. Sekarang orang Farisi yang sombong ini berubah menjadi seorang yang kesakitan, gemetar, meraba-raba dan bergantung pada tangan orang lain yang menuntunnya sampai ia tiba di Damsyik. Ia pergi ke rumah Yudas dan langsung masuk ke kamarnya. Di sana ia tinggal selama tiga hari tanpa makanan dan minuman. Selama tiga hari itu Paulus berdoa dan berpuasa. Seluruh hidupnya telah berubah setelah pertemuannya dengan Kristus. Sekarang dia harus membangun kembali kehidupannya di dalam Kristus. Pola hidupnya harus berubah seratus persen karena Yesus telah bekerja di dalamnya melalui karya-Nya yang ajaib. "Pertobatan Paulus menjadi awal visi dan misinya."121

Pengalaman Paulus dalam perjalanan menuju Damsyik hamper selalu disebut sebagai pertobatannya, meskipun istilah ini tidak pernah digunakan, baik oleh Lukas maupun oleh Paulus sendiri dan seringkali diyakini sebagai bentuk definitive dari sebuah bentuk pertobatan yang sejati. ${ }^{122}$

${ }^{121}$ Darmawaijaya, Kisah Para Rasul (Yogyakarta: Kanisius, 2006), 118

${ }^{122}$ Peter Walker, In The Steps of Saint Paul

(Yogyakarta: Kanisius, 2009), 19
Jadi pernyataan Dari dalam gelap akan terbit terang adalah peribahasa dari kisah hidup Paulus yang hendak dibagikan kepada jemaat di Korintus. Paulus yang dulu hidupnya ada didalam kegelapan dan bahkan menjadi penganiaya jemaat, oleh kemurahan Tuhan ia telah dipanggil untuk memberitakan Injil kebenaran.

\section{KEPUSTAKAAN}

Abineno, J.L Ch., Pokok-Pokok Penting Dari Iman Kristen. Jakarta: BPK Gunung Mulia, 1999.

Bambang, Yohanes C.W., Kristologi.

Mojokerto: Gereja Ortodox Indonesia, t.t.

Beyer, Ulrich \& Evalina Simamora, Memberi Dengan Sukacita. Jakarta: BPK Gunung Mulia, 2008.

Brill, J. Wesley, Dasar Yang Teguh.

Bandung: Yayasan Kalam Hidup, 1999.

Darmawaijaya, Kisah Para Rasul.

Yogyakarta: Kanisius, 2006.

Martasudjita, E. Pr., Spiritualitas Damai.

Yogyakarta: Kanisius, 2008.

Pfitzner, V.C. Kesatuan Dalam

Kepelbagaian, Pentj. Sthephen Suleeman. Jakarta:

BPK Gunung Mulia, 2006.

Walker, Peter, In The Steps of Saint Paul.

Yogyakarta: Kanisius, 2009.

White, Jerry, Kejujuran Moral dan Hati

Nurani. Jakarta: BPK Gunung Mulia, t.t. 